\title{
TRANSLATING SCIENTIFIC TERMS ACROSS EUROPEAN AND AFRICAN LANGUAGES-PHYSICS IN NGUNI II
}

Temba S. Dlodlo 1

National University of Science and Technology, Bulawayo, Zimbabwe

\begin{abstract}
The use of European languages as languages of instruction in education continues in many Sub-Saharan African countries, in spite of several decades of political independence. This is also the situation in science teaching. Several studies have shown that children learn best when taught in their own mother languages. Teaching in these languages necessitates translation of science terms and concepts into Indigenous languages. Using quantum mechanics, a field in modern physics and my mother tongue, isiNguni, as an example, I have developed translation strategies and suggested practical approaches to create science vocabulary in isiNguni. It is shown that it is feasible to apply direct borrowing with localisation and semantic extension in developing new physics vocabulary. Several examples of translated science terms and concepts in isiNguni are provided. Selected paragraphs on electron spin from a frequently used undergraduate physics textbook are translated into isiNguni. In the Appendices, the Compton effect experiment is presented in three languages accompanied by a vocabulary. African countries need to revise their language and education policies so that maximum use of the Indigenous languages and the future relevance of these languages in science and technology are ensured. Teaching physics and other science subjects in the mother tongues of both teachers and students will improve science literacy, comprehension, and interest in the field. Africa should embrace science and technology to contribute to new knowledge.
\end{abstract}

Keywords: Indigenous languages, creating science terminology, translation, Africa

Citation: Dlodlo T. S. (2021). Translating scientific terms across European and African languages-Physics in Nguni II. WINHEC: International Journal of Indigenous Education Scholarship, 16(1), pp. 91-112. http://dx.doi.org/10.18357/wj1202120276. Special Issue on Indigenous Language Revitalization: Innovation, Reflection and Future Directions, Guest Co-Editors Drs. Onowa McIvor and Kari A. B. Chew.

\footnotetext{
${ }^{1}$ Correspondence: Temba S. Dlodlo, Applied Physics Department, National University of Science and Technology, Bulawayo, Zimbabwe, tsdlodlo@hotmail.com
} 


\section{Introduction}

In Sub-Saharan Africa, establishment of institutions, such as schools, hospitals, and justice systems, resulted in the introduction of new concepts and hence new terms into the vocabularies of African languages. Many new words were developed using direct borrowing and localisation, for example, in isiNguni: ${ }^{2}$ teacher $=$ uthisha, nurse $=$ unesi, doctor $=$ udokotela, and police $=$ ipholisa. While it can be argued that such subjects as mathematics, biology, chemistry and physics have scientific terms that needed to be created in the Indigenous languages, there is no explanation why non-science subjects, such as history, law, social studies and others, are still taught in European languages.

Science nomenclature had to be developed in European languages, for example, in English. To illustrate this point, a description of Michael Faraday's struggles to create terms for the then new phenomena connected to the discovery of electricity (Sutton, 1992) is included here:

[We] talk of anodes and cathodes, and even of ions ... without knowing anything of the struggles that Michael Faraday had in 1833-4 to decide how to express his ideas about this topic. He asked William Whewell ...what words would be most helpful.... Whewell drew on his mastery of Greek to favour "anode and cathode" (the way up and the way down) for what Faraday was trying to express, rather than "eisode and exode" (the way in and the way out) and certainly rather than "eriode and occiode" or "eastode and west-ode" which came from Faraday's thoughts about electricity and the earth's magnetism. Faraday had tried "electobeid" ("electrical goer") ... and Whewell

\footnotetext{
${ }^{2}$ Nguni languages are one of the largest language groups of southern Africa.
} 
suggested simply "ion" to allow "cation" at the cathode and "anion" at the anode. (p. 15)

The same needs to be done in the Indigenous languages of Africa to ensure their wide use in every sphere of life and their continued development and relevance. It has also been shown (Bamgbose, 1984) that children taught in their mother languages learn better than children taught in their second language. It follows that it is essential to develop strategies for development of science vocabulary in the Indigenous African and other languages in spite of doubts expressed by some researchers as to "the translatability of academic discourse from English into an African language" (Wildsmith-Cromarty, 2008, p. 147). It is also noted that in countries such as Russia, China, and Japan, students learn about, for example, the Compton effect in their own mother languages written in the non-Roman alphabet. This is the same physics of the Compton effect that African students must learn in the European languages of the past colonialists, yet they cannot articulate it in their own mother languages.

This paper aims to i) stimulate debate on the feasibility of the use and promotion of African languages for science education in schools and universities and ii) demonstrate possible strategies to develop science and technology terminology in the Indigenous languages. Translation of selected terms that one encounters in the study of modern physics in the form of quantum mechanics from English to isiNguni will be discussed, and improvements on previous strategies will be made (Dlodlo, 1999). 
An English-isiZulu-English dictionary (Doke et al., 1958), an isiZulu dictionary (Nyembezi, 1992) that explains the meanings of isiZulu words in isiZulu, an isiNdebele dictionary (Hadebe, 2001) that explains the isiNdebele terms in isiNdebele, and a dictionary of physics that explains the English physics terms in English (McGraw-Hill, 2002) have been used.

The paper has four tables listing selected science concepts that already exist in isiNguni and showing examples of different translation strategies. Two paragraphs of a physics textbook that has been read at some universities over the years are translated from English to isiNguni to demonstrate use of the proposed approaches. In Appendix A, to show that scientific text can be translated from European to Indigenous languages without loss of meaning, a scientific text is presented in two European languages where the Dutch language of the Netherlands is the source language for the translation into isiNguni. isiNguni is then made the source language for the translation into the English language. Appendix B summarises the key vocabulary used in translating the Compton Effect in three languages. ${ }^{3}$

\section{The Translation Strategies}

\section{About Nguni Languages}

The Nguni languages (isiNguni) include Ndebele, Swati, Xhosa, and Zulu and are spoken in southern Africa by approximately 30 million people ("Nguni people," 2020). They are recognised as official languages in South Africa, Eswatini, and Zimbabwe and are used, for example, in mass media. However, they are not used as languages of instruction in schools and universities, except during early years of primary education. The language of instruction

\footnotetext{
${ }^{3}$ Appendix B serves, together with other translation charts throughout, in place of a Glossary for this article.
} 
is English, and teaching in the African national languages is offered as a subject, like European/"foreign" languages. It follows that the Nguni languages could be considered "vulnerable," that is, spoken by most children and their use restricted to certain domains (UNESCO, 2020).

Nouns are grouped into eight classes according to their prefixes in the Nguni languages. Prefixes are not indicative of gender. Concord, that is a word subordinate to a noun must show its agreement with the class of that noun, is essential. There is a high development of verb tenses and many verbal derivatives. All Nguni languages employ click sounds (Nyembezi, 1978). There are five vowels, and the consonants exclude "r."

\section{Proposed Approaches of Creating New Physics Terms and Examples}

Certain science vocabulary already exists in isiNguni (Table 1). These and other existing words could be put into immediate use.

\section{Table 1}

Examples of Science Concepts That Exist in isiNguni ${ }^{4}$

\begin{tabular}{|l|l|l|l|}
\hline \multicolumn{1}{|c|}{ English Term } & \multicolumn{1}{|c|}{ Nguni Term } & English Term & \multicolumn{1}{c|}{ Nguni Term } \\
\hline Force & udli, indlovula & Width & ububanzi \\
\hline Energy & isidlakadla & Speed & ijubane \\
\hline Power & amandla & Velocity & isivinini \\
\hline Strength & isidladla & Acceleration & isiqubu \\
\hline Length & ubude & Photons & $\begin{array}{l}\text { inhlamvu zelanga = particles of the } \\
\text { sun }\end{array}$ \\
\hline
\end{tabular}

\footnotetext{
${ }^{4}$ Examples of isiNguni noun prefixes in Table 1 include "u," “ubu," “i," "in," "isi," and "a."
} 
It is necessary to create new science words in isiNguni. This can be done through the use of direct borrowing with localisation and semantic extension. It is proposed that direct borrowing with localisation be used sparingly because it results in "meaningless" words and that it be employed only for names of particles and equipment. Some examples are shown in Table 2.

\section{Table 2}

Examples of Direct Borrowing with Localisation for Creating New Nguni Physics Terms

\begin{tabular}{|l|l|l|l|}
\hline \multicolumn{1}{|c|}{ English Term } & \multicolumn{1}{c|}{ Nguni Term } & \multicolumn{1}{c|}{ English Term } & \multicolumn{1}{c|}{ Nguni Term } \\
\hline Electron & i-elekthoni & Fermion & ifemiyoni \\
\hline Photon & ifothoni & Boson & ibosoni \\
\hline Neutron & inutloni & Phonon & ifononi \\
\hline Proton & iplothoni & Atom & i-ithomu \\
\hline Ion & iyoni & Molecule & imolenkulu \\
\hline Vector & ivektha & Entropy & i-entophi \\
\hline
\end{tabular}

There are many words for new concepts that have been introduced into the isiNguni vocabulary through semantic extension, for example, isibuko $=$ mirror (from buka $=$ admire/look at); umabonakude = television (from bona = see; kude = far). Semantic extension can also be used to create new Nguni physics terms by combining existing words to create one word or simply using a word in a science context by creating verbs out of nouns or nouns out of verbs. Examples are shown below and in Table 3:

For: i) Physics $=$ infundanvelo, the words are infundo (knowledge) + invelo (nature) $=$ learning of nature.

ii) Interaction = inzelana, the word is enzelana (do for/unto one another).

iii) Quantum mechanics = infundanyakazo yobuqanyana, the 
combined words are infundo (knowledge) + unyakazo (motion),

yobuqa- (of quanta) and -nyana (is a suffix for infinitely small).

iv) Polynomial of $\mathrm{z}=$ inhlanganiswa yeziya zika $\mathrm{z}$, the combined words

are inhlanganiswa (the sum) + yeziya (of the functions) + zika z (of z).

v) Degenerate energy level = izinga lesidlakadla elisesithenjini, the

words are izinga (the level) lesidlakadla (of energy) elisesithenjini

(that is in multiple/polygamous relationships).

\section{Table 3}

Examples of Use of Semantic Extension for Creating New Nguni Physics Terms

\begin{tabular}{|c|c|c|c|}
\hline English Term & $\begin{array}{c}\text { Nguni } \\
\text { Translation }\end{array}$ & The Nguni Words & $\begin{array}{l}\text { English Literal } \\
\text { Translation }\end{array}$ \\
\hline Physics & infundanvelo & $\begin{array}{l}\text { infundo = knowledge, invelo } \\
=\text { nature }\end{array}$ & learning of nature \\
\hline Mechanics & infundanyakazo & $\begin{array}{l}\text { infundo }=\text { knowledge } \\
\text { nyakazo }=\text { motion }\end{array}$ & learning of motion \\
\hline $\begin{array}{l}\text { Quantum } \\
\text { mechanics }\end{array}$ & $\begin{array}{l}\text { infundanyakazo } \\
\text { yobuqanyana }\end{array}$ & $\begin{array}{l}\text { infundanyakazo = } \\
\text { mechanics, } \\
\text { yobuqa- = of quanta, -nyana } \\
\text { is a suffix for infinitely small }\end{array}$ & $\begin{array}{l}\text { learning of the } \\
\text { motion of quanta }\end{array}$ \\
\hline Mathematics & infundazibalo & izibalo = numbers & learning of numbers \\
\hline Matter field & iguma lebumba & $\begin{array}{l}\text { iguma }=\text { area, ibumba }= \\
\text { matter }\end{array}$ & $\begin{array}{l}\text { an area where matter } \\
\text { is located }\end{array}$ \\
\hline Wave function & isiya segagasi & $\begin{array}{l}\text { iya }=\text { it goes as, igagasi = } \\
\text { wave }\end{array}$ & $\begin{array}{l}\text { the function of the } \\
\text { wave }\end{array}$ \\
\hline Hydrogen & indalamanzi & dala $=$ create manzi $=$ water & creator of water \\
\hline Oxygen & impilisa & impilo = life, health & sustainer of life \\
\hline Nitrogen & isihitsha & ukuhitsha $=$ suffocate & that which suffocates \\
\hline Nucleus & $\begin{array}{l}\text { umongo we } \\
\text { athomu }\end{array}$ & $\begin{array}{l}\text { mongo }=\text { core, we athomu }= \\
\text { of the atom }\end{array}$ & the core of the atom \\
\hline $\begin{array}{l}\text { Polynomial of } \\
\mathrm{z}\end{array}$ & $\begin{array}{l}\text { inhlanganiswa } \\
\text { yeziya zika z }\end{array}$ & $\begin{array}{l}\text { inhlanganiswa= sum of, } \\
\text { yeziya = of the functions, of } \mathrm{z} \\
=\text { zika } \mathrm{z}\end{array}$ & $\begin{array}{l}\text { the sum of the } \\
\text { functions of } z\end{array}$ \\
\hline $\begin{array}{l}\text { Power series } \\
\text { of } \mathrm{z}\end{array}$ & $\begin{array}{l}\text { udwendwe } \\
\text { emandleni ka z }\end{array}$ & dwendwe = que $/$ file & $\begin{array}{l}\text { a series of terms in } \\
\text { powers of } z\end{array}$ \\
\hline
\end{tabular}




\begin{tabular}{|l|l|l|l|}
\hline & & $\begin{array}{l}\text { emandleni ka } \mathrm{z}=\text { in powers } \\
\text { of z }\end{array}$ & udliki= potential, isifu = trap \\
\hline Potential box & udliki oluyisifu & $\begin{array}{l}\text { a potential that is a } \\
\text { trap }\end{array}$ \\
\hline $\begin{array}{l}\text { Potential } \\
\text { barrier }\end{array}$ & $\begin{array}{l}\text { udliki } \\
\text { oluyisivimbelo }\end{array}$ & $\begin{array}{l}\text { udliki = potential, oluyi = that } \\
\text { is, isivimbelo = a barrier } \\
\text { barrier }\end{array}$ \\
\hline $\begin{array}{l}\text { Equilibrium } \\
\text { separation }\end{array}$ & $\begin{array}{l}\text { ibanga eliyi } \\
\text { nhlukanisa } \\
\text { kungena } \\
\text { nyakazo }\end{array}$ & $\begin{array}{l}\text { ibanga = distance, eliyi }= \\
\text { that is, nhlukanisa = a } \\
\text { separator, kungena = in the } \\
\text { absence of, nyakazo = } \\
\text { motion }\end{array}$ & $\begin{array}{l}\text { a separation- } \\
\text { distance with no } \\
\text { motion }\end{array}$ \\
\hline $\begin{array}{l}\text { Symmetry/ } \\
\text { (anti- } \\
\text { symmetry) }\end{array}$ & $\begin{array}{l}\text { ukufana xathu } \\
\text { kwenhlangothi/ } \\
\text { (-zifulathelene) }\end{array}$ & $\begin{array}{l}\text { fana xathu = identical, } \\
\text { kwenhlangothi = of sides } \\
\text { /zifulathelene = turned back } \\
\text { on back }\end{array}$ & $\begin{array}{l}\text { like pairs/like pairs } \\
\text { turned back on back }\end{array}$ \\
\hline $\begin{array}{l}\text { Degenerate } \\
\text { energy level }\end{array}$ & $\begin{array}{l}\text { izinga } \\
\text { lesidlakadla } \\
\text { elisesithenjini }\end{array}$ & $\begin{array}{l}\text { izinga = level, isidlakadla }= \\
\text { energy, esisesithenjini = } \\
\text { polygamous/belonging to } \\
\text { more than one state }\end{array}$ & $\begin{array}{l}\text { an energy level that is } \\
\text { in a polygamous } \\
\text { relationship }\end{array}$ \\
\hline
\end{tabular}

Children are taught at school in English that air is a mixture of nitrogen, oxygen and other gases and that water is a compound of hydrogen and oxygen. Interestingly, in Dutch, oxygen $=$ zuurstof (the stuff of sourness), hydrogen $=$ waterstof (the stuff of water), and nitrogen $=$ stikstof (the stuff that suffocates), and the same approach has been applied here for isiNguni terms of impilisa for oxygen, indalamanzi for hydrogen, and isihitsha for nitrogen.

Table 4 presents Nguni physics terms formulated from words to which scientific meaning has been attached. Some words or parts of the word may already exist but may not have been used in a science context. 
Table 4

Examples of New Nguni Physics Terms Based on Words to Which Scientific Meaning Has Been Attached

\begin{tabular}{|c|c|c|}
\hline $\begin{array}{l}\text { English } \\
\text { Term }\end{array}$ & Nguni Term & English Explanation of the Nguni Term \\
\hline Potential & udliki & udli $=\mathrm{a}$ force , from which udliki = potential is created \\
\hline Momentum & isivungudla & $\begin{array}{l}\text { from isivunguzane }=\text { whirlwind from which } \\
\text { isivungudla = momentum is created }\end{array}$ \\
\hline Moment & isivungu & $\begin{array}{l}\text { from isivunguzane }=\text { a strong wind (whirlwind) capable of } \\
\text { lifting objects }\end{array}$ \\
\hline Dipole & imbelo & two poles that are a very short distance apart \\
\hline $\begin{array}{l}\text { Electric } \\
\text { dipole } \\
\text { moment }\end{array}$ & $\begin{array}{l}\text { isivungu } \\
\text { sembelo } \\
\text { yegetsi }\end{array}$ & $\begin{array}{l}\text { imbelo is an arrangement of two poles, a short distance } \\
\text { apart. So that isivungu sembelo yegetsi = electric }(+/-) \\
\text { dipole moment }\end{array}$ \\
\hline $\begin{array}{l}\text { Magnetic } \\
\text { dipole } \\
\text { moment }\end{array}$ & $\begin{array}{l}\text { isivungu } \\
\text { sembelo } \\
\text { wobuwonga }\end{array}$ & $\begin{array}{l}\text { imbelo is an arrangement of two poles, a short distance } \\
\text { apart. So that isivungu sembelo wobuwonga = magnetic } \\
(\mathrm{N} / \mathrm{S}) \text { dipole moment }\end{array}$ \\
\hline Model & infanisela & $\begin{array}{l}\text { that which is imagined to be/has a resemblance to/a } \\
\text { picture of }\end{array}$ \\
\hline Theory & infunisela & $\begin{array}{l}\text { that which one wants or hopes could be or is/thought } \\
\text { process }\end{array}$ \\
\hline Angle & inkomba & that which indicates a direction \\
\hline
\end{tabular}

Text box 1 below presents a verbatim translation of two paragraphs of Section 3.7 of a physics textbook: Fundamental University Physics III (Alonso \& Finn, 1968, p. 135) from English to isiNguni applying the above-mentioned strategies for creating new science vocabulary.

\section{Text Box 1}

Translation from English to isiNguni of Two Paragraphs of Section 3.7 of a Physics Textbook: Fundamental University Physics III (Alonso \& Finn, 1968) 


\section{Electron Spin}

Let us recall, that the earth in addition to its orbital motion around the sun, has $a$ rotational or spinning motion about its axis. Therefore, the total angular momentum of the earth is the vector sum of its orbital angular momentum and its spin angular momentum. By analogy we may suspect that a bound electron in an atom is also spinning. However, we cannot describe the electron as a spherical spinning particle because of our ignorance of its internal structure. Thus we cannot compute the spin angular momentum of the electron in the same way that we compute the spin angular momentum of the earth in terms of its radius and angular velocity. The idea of electron spin was first proposed in 1926 by G. Uhlenbeck and S. Goudsmit to explain certain features of the spectra of one - electron atoms. If $\mathrm{S}$ is the spin angular momentum of an electron and Lis the orbital angular momentum, the total angular momentum $\mathrm{J}=\mathrm{L}+\mathrm{S}$. For given values of $\mathrm{L}$ and $S$, the value $\mathrm{J}$ depends on their relative orientation, and we may expect this to be reflected in certain atomic properties; this indeed is the case. The existence of electron spin is borne out by a large accumulation of experimental evidence. For an example, electro spin is manifested in a very direct way by the Stern-Gerlach experiment, first performed in 1924. Because the electron is a charged particle, electron spin should result in an intrinsic or spin magnetic dipole moment $\mathrm{M}_{\mathrm{S}}$ of the electron. If the electron could be described as a rotating rigid charged body, the relation between $\mathrm{M}_{\mathrm{S}}$ and $\mathrm{S}$ would be the same as between
Ushwilizane lwe elekthoni

Masikhumbule ukuba umhlaba ngaphandle konyakazo lwawo uzungeza ilanga, unonyakazo lokushwiliza noma olokumpininiza ngogalo lwawo lomkhathi.Yikho iqoqo lesivungudla senkomba somhlaba siliqoqo lama vektha awo, elenzungezane neloshwilizane. Sifanisela singacabanga ukuthi elekthoni elikhulekelwe ku athomu yalo nalo liyashwiliza. Kodwa singeke sichaze elekthoni njengo hlanjana olushwiliza luyi ndilingana ngoba singasazi isakhiwo salo. Ngalokho singeke sasibala isivungudla senkomba soshwilizane lwe elekthoni njengalokho sibala isivungudla senkomba yomhlaba ngokwazi ugalo lwendilinga nesivinini senkomba. Umnakano wokushwiliza kwe elekthoni wasongozwa ngo 1926 ngu G. Uhlenbeck no S. Goudtsmit ukuze kucace okuvezwa zinxuku zenvama zama athomu asa-ndalamanzi. Uma S

kuyisivungudla senkomba yoshwilizane lwe elekthoni njalo L kuyisivungudla senkomba senzungezane, iqoqo lesivungudla senkomba yileli J = L + S. Ngalinye lamanani ka L no S, inani lika J liya ngomelwana lwawo, okuyikho okumele kuvezwe ngezinye impawu zama athomu; njalo yikho okutholakalayo. Ukubakhona koshwilizane lwe elekthoni kufakazwa yizilinga eziningi. Ngomzekelo, ushwilizane lwe elekthoni luvezwa obala yisilinga esithiwa yi Stern-Gerlch esenziwa ngokokuqala ngo 1924. Ngenxa yokuba elekthoni liqukethe inhlasi, ushwilizane kumele luveze isivungu sembelo yewonga $\mathrm{M}_{\mathrm{S}}$ se elekthoni. Uma elekthoni liyisibunjwa esiyitshe esiquketheyo njalo esizungezayo, ubuhlobo obukhona phakathi kuka $\mathrm{M}_{\mathrm{S}}$ no $\mathrm{S}$ kumele bufane nalobo obukhona phakathi kuka $\mathrm{M}_{\mathrm{L}}$ no L. Kodwa akunjalo, kumele sibhale:

$$
\mathrm{M}_{\mathrm{S}}=-\mathrm{g}_{\mathrm{S}} \frac{\mathrm{e}}{2 \mathrm{~m}_{\mathrm{e}}} \mathrm{S}
$$




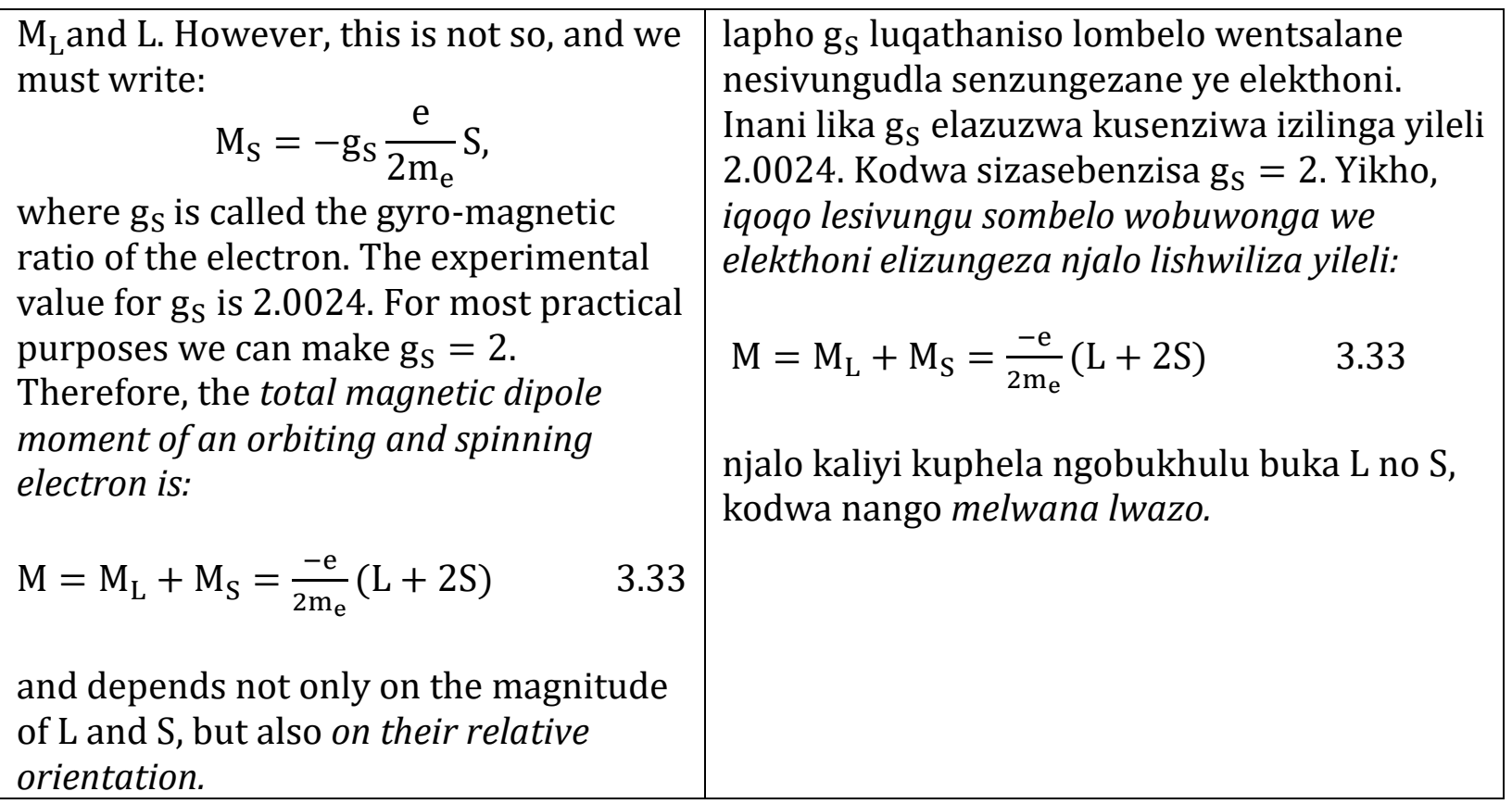

\section{Discussion}

This paper suggests that it is feasible to create new terms in, for example, quantum mechanics, in Indigenous languages using isiNguni as an example and proposes strategies for their development. In certain instances, direct borrowing is appropriate. To enhance meaningfulness of the new terms, it should be kept to a minimum, and semantic extension could be a more proper approach. It is possible to use words and combinations of words of everyday language, assign new scientific meaning to them, and create new terms.

"Word-order difficulties" (Strevens, 1976, p. 56) are a necessity if the translation is to be accurate, for example, magnetic dipole moment = isivungu (the moment) sembelo (of the poles) yewonga (of a magnet). The resulting new term is more appropriate than direct borrowing with localisation (maginethikhi dayipolu momenti) because the latter is meaningless, as none of these three words exist in isiNguni. At times, long phrases are 
required to translate complex concepts, for example, $\mathrm{g}: \mathrm{g}_{\mathrm{S}}=$ gyro-magnetic ratio constant is $\mathrm{g}: \mathrm{g}_{\mathrm{S}}=$ yisimanjalo esiluqathaniso lwesivungu sembelo yewonga loshwilizane nesivungu senkomba soshwilizane, that is, the ratio/comparison of the spin magnetic dipole moment and the spin angular momentum, in English, rather than igayiro-maginethikhi reshiyo, which would be very unhelpful.

Ademowo (2010) has defined the Pragmatic Approximating Process (PAP) proposed by Owolabi (2006) as the "process of painstaking thinking, discussing, explaining, and approximating new words in translating scientific concepts and theories from foreign to Indigenous languages without any possibility of loss in meaning occasioned by cross-cultural translation" (p. 58). The goal of the PAP strategy is stated to be that of "evolving a manual that will make scientific terms intelligible in the native/indigenous languages" (p. 59). The goal of this paper is rather to advocate for development of science terminology and literature so as to facilitate teaching sciences in Indigenous African and other languages, that is, in mother tongues of both students and teachers, as is done in Europe and Asia.

\section{Conclusion}

The English language continues to be used extensively not only in places of learning but also at work and home in the ex-British colonies in Sub-Saharan Africa several decades after the countries gained independence. Lack of use of the Indigenous languages in education, commerce, and administration makes them vulnerable and poses a threat of their use becoming limited to selected domains. One of the first steps of expanding the use of Indigenous languages should be education where they should become the mediums of 
instruction. Learning in one's own mother tongue will improve comprehension of science subjects among students and increase pass rates when students are able to understand the concepts. Their teachers can provide eloquent explanations when everyone is using their mother language.

Creating science nomenclature in the Indigenous languages is feasible and Indigenous languages around the world can be used for all communication, including scientific discourse. It requires political will, resources, and training of terminologists and subject specialists who are competent in both the source and Indigenous languages. It also requires multisectoral engagement to review existing language and education policies to ensure the place that the Indigenous languages deserve.

Africa must realise that for the continent to make strides in economic development, it must participate in the advancement of science and technology and contribute new knowledge. If the use of African languages in education is not promoted, there will be no growth in learning science and no corresponding growth in the development of science and technology terminology. This is likely to limit the use of Indigenous African languages and let their speakers remain illiterate in science. Creating new scientific vocabulary in the Indigenous languages will result in the development and continued relevance of these languages. 


\section{About the Author}

Temba S. Dlodlo is physicist at National University of Science and Technology in Zimbabwe. He graduated with MSc Eng degree in Laser Physics at the Delft University of Technology in the Netherlands and earned a PhD in Laser Physics from the University of Helsinki in Finland. He is interested in science education.

\section{References}

Ademowo, A. J. (2010). Teaching science and technology: The employment of Indigenous African languages. Journal of Pan African Studies, 3(9), 50-63.

Alonso, M., \& Finn, E. (1968). Fundamental university physics (Vol. III). Quantum and statistical mechanics. Addison-Wesley Publishing Company.

Bamgbose, A. (1984). Mother-tongue medium and scholastic attainment in Nigeria. Prospects, 14, 87-93.

Dlodlo, T. S. (1999). Science nomenclature in Africa: Physics in Nguni. Journal of Research in Science Teaching, 36(3), 321-331.

Doke, C. M., McK. Malcolm D., \& Sikakana, J. M. A. (1977). English and Zulu dictionary. Witwatersrand University Press.

Hadebe, S. (2001). Isichazamazwi SesiNdebele. College Press Publishers.

McGraw-Hill. (2003). McGraw-Hill dictionary of physics. (3 $3^{\text {rd }}$ ed.)

Nguni people. (2020, December 31) In Wikipedia. https://en.wikipedia.org/wiki/Nguni_people

Nyembezi, S. (1978). Learn Zulu. Shuter \& Shooter.

Nyembezi, S. (1992). Isichazimazwi Sanamuhla Nangomuso. Reach Out Publishers.

Owolabi, K. (2006). Nigeria's native language modernization in specialized domains for national development: A linguistic approach: an inaugural lecture delivered at the University of Ibadan on Thursday, 29 June, 2006. Universal Akada Books.

Strevens, P. (1976). Problems of learning and teaching science through a foreign language. Studies in Science Education. 3, 55-68.

Sutton, C. R. (1992). Fossils of old thoughts. In Words, science and learning (p. 15). Open University Press. https://doi.org/10.1016/0307-4412(92)90211-4 
UNESCO. (2020, December 31). Atlas of the world's languages in danger. http://www.unesco.org/languages-atlas/

Wildsmith-Cromarty, R. (2008). Can academic/scientific discourse really be translated across English and African Languages? Southern African Linguistics and Applied Language Studies, 26(1), 147-169.

https://doi.org/10.2989/SALALS.2008.26.1.12.427 


\section{Appendix A}

\section{The Compton Effect in Three Languages}

\section{Nederlands (Dutch)}

Laat men een elektromagnetisch straling vallen op, bijvoorbeeld een blok grafiet, dan neemt men een electromagnetisch straling waar die zijdelings uit het blok treedt, zogenaamd verstrooide strallng. De golflengte van de verstrooide stralling is groter dan die van de invallende stralling. De golflengteverandering $\Delta \lambda$ is groter naarmate de verstrooiings hoek $\theta$ groter is. Een verklaring van dit verschijnsel op basis van de klassieke golftheorie is onmogelijk. Compton liet echter zien dat de verstrooiing invoudig te begrijpen is, als deze beschreven wordt als een botsingsproces tussen een foton en een stilstaande vrij elektron.

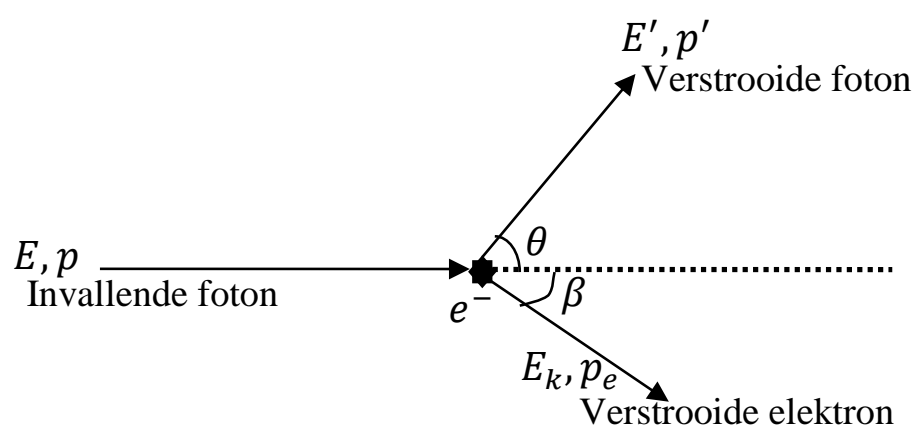

Figuur 11: Verstrooiing van een langs de $x$-as invallend foton $h v$ aan een stilstande en vrij elektron. Volgens de vetten van behoud van energy en impuls: $E_{k}=E-E^{\prime}$ en $p_{e}=p-p^{\prime}$, met $p=p^{\prime} \cos \theta+p_{e} \cos \beta$ and $p^{\prime} \sin \theta=p_{e} \sin \beta$

Toepasing van de wetten van het behoud van impuls en energie levert, dan als $\mathrm{p}$, E de impuls en de energie van het invallende foton en $\mathrm{p}^{\prime}, \mathrm{E}^{\prime}$ de impuls en energie van het verstrooide foton is:

$$
p=p^{\prime}+p_{e} \text { met } p_{e}=p-p^{\prime}
$$


$\mathrm{E}+\mathrm{mc}^{2}=\mathrm{E}^{\prime}+\sqrt{\mathrm{m}_{\mathrm{o}}^{2} \mathrm{c}^{4}+\mathrm{p}_{\mathrm{e}}^{2} \mathrm{c}^{2}}$

de terugslag impuls van de elektron. Kwadrateer $p_{e}=p-p^{\prime}$ en uit

$\mathrm{p}_{\mathrm{e}}^{2}=\mathrm{p}^{2}+\mathrm{p}^{\prime 2}-2 p \mathrm{p}^{\prime} \cos \theta ;$ met $\mathrm{p}=\frac{\mathrm{E}}{\mathrm{c}}=\frac{\mathrm{h} v}{\mathrm{c}}=\frac{\mathrm{h}}{\lambda}$,

en $p^{\prime}=\frac{E^{\prime}}{c}=\frac{h v^{\prime}}{c}=\frac{h}{\lambda^{\prime}}$ krijgt men $p_{e}^{2}=\frac{1}{c^{2}}\left(E^{2}+E^{\prime 2}-2 E E^{\prime} \cos \theta\right)$

Uit 11.6 volgt $p_{e}^{2}=\frac{1}{c^{2}}\left[E^{2}+E^{\prime 2}-2 E E^{\prime}+2\left(E-E^{\prime}\right) m_{e} c^{2}\right]$

Vergelijkingen 11.7 en 11.8 tonen dat:

$\mathrm{E}-\mathrm{E}^{\prime}=\frac{\mathrm{EE}^{\prime}}{\mathrm{m}_{\mathrm{e}} \mathrm{c}^{2}}(1-\cos \theta)$, zodat met $\mathrm{E}=\mathrm{h} v=\frac{\mathrm{hc}}{\lambda}$, krijgt men

$\lambda^{\prime}-\lambda=\lambda_{C}(1-\cos \theta)$

$\lambda_{\mathrm{C}}=\frac{\mathrm{h}}{\mathrm{m}_{\mathrm{e}} \mathrm{c}}$ de zogenaamd Compton golflengte.

Opgave: Beschouw een bundel fotonen met $\lambda=0.1 \mathrm{~nm}$ en een met $\lambda=0.002 \mathrm{~nm}$. Als de straling door vrije elektronen verstrooid wordt over $90^{\circ}$, hoe groot is dan de golflengteverandering in elke van deze gevalen?

\section{IsiNguni}

Singathatha inkanyiso yewongagetsi siyiwisele ebusweni besibunjwa esinjengomkhumence sizabona enye inkanyiso yewongagetsi eyinhlakazane ivela eceleni komkhumence. Sizananzelela ukuba ubudebegagasi lenkanyiso eyinhlakazane bukhulu kunalobo obenkanyiso ewelayo. Umehluko wobude bamagagasi la $\Delta \lambda$ uya ukhula ngokhula kwezinga lenkomba $\theta$ yenkanyiso eyinhlakazane. Isimanga lesi kasichasiseki ngenfundavelo yamagagasi yendulo. Noma kunjalo Compton watshengisa ukuthi ukubakhona 
kwenhlakazane yenkanyiso yewongagetsi, kuchasiseka lula uma kungathathwa njengongquzulwana lwe fothoni nohlanjana oluyabuzela lundawonye.

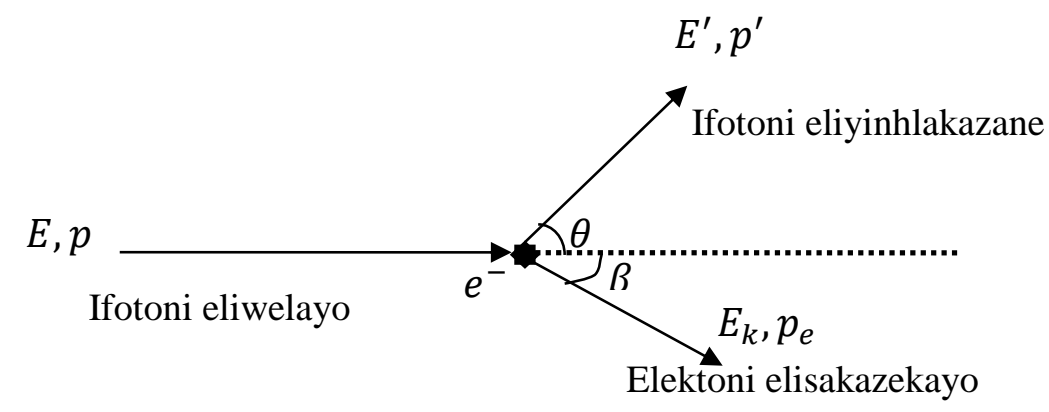

Isifanekiso 11: Ukuhlakazwa kwefotoni hv, eliwela ngogalo - $\mathrm{x}$ ku elektoni eliyabuzela ndawonye.

Kulandelwa imithetho yokongeka kwesidlakadla nesivungudla : $E_{k}=E-E^{\prime}$ njalo $\mathbf{p}_{\mathbf{e}}=\mathbf{p}-\mathbf{p}^{\prime}$ no $\mathbf{p}=$ $p^{\prime} \cos \theta+p_{e} \cos \beta$ futhi $p^{\prime} \sin \theta=p_{e} \sin \beta$

Singasebenzisa imithetho yokongeka kwesivungudla nesidlakadla, uma p, E kuyisivungudla nesidlakadla sefothoni eliwelayo njalo $\mathrm{p}^{\prime}, \mathrm{E}^{\prime}$ kuyisivungudla nesidlakadla sefothoni eliyinhlakazane, sizathola lezi izibalo:

$\mathrm{p}=\mathrm{p}^{\prime}+\mathrm{p}_{\mathrm{e}}$, njalo $\mathrm{p}_{\mathrm{e}}=\mathrm{p}-\mathrm{p}^{\prime}$

$\mathrm{E}+\mathrm{mc}^{2}=\mathrm{E}^{\prime}+\sqrt{\mathrm{m}_{\mathrm{o}}^{2} \mathrm{c}^{4}+\mathrm{pe}_{\mathrm{e}}^{2} \mathrm{c}^{2}}$

Kusibalo $11.5 \mathrm{p}_{\mathrm{e}}=\mathrm{p}-\mathrm{p}^{\prime}$ yisivungudla elekthoni elikhwincika ngaso.

Lapha $\mathrm{p}_{\mathrm{e}}=\mathrm{p}-\mathrm{p}^{\prime}$ angaphiwa amandla kabili sithola lokhu:

$\mathrm{p}_{\mathrm{e}}^{2}=\mathrm{p}^{2}+\mathrm{p}^{\prime 2}-2 \mathrm{p} \mathrm{p}^{\prime} \cos \theta ;$ njalo $\mathrm{p}=\frac{\mathrm{E}}{\mathrm{c}}=\frac{\mathrm{h} v}{\mathrm{c}}=\frac{\mathrm{h}}{\lambda}$,

no $\mathrm{p}^{\prime}=\frac{\mathrm{E}^{\prime}}{\mathrm{c}}=\frac{\mathrm{h} v^{\prime}}{\mathrm{c}}=\frac{\mathrm{h}}{\lambda^{\prime}}$ yikho $\mathrm{p}_{\mathrm{e}}^{2}=\frac{1}{\mathrm{c}^{2}}\left(\mathrm{E}^{2}+\mathrm{E}^{\prime 2}-2 \mathrm{EE}^{\prime} \cos \theta\right)$

Kusuka ku 11.6 kulandela: $p_{\mathrm{e}}^{2}=\frac{1}{\mathrm{c}^{2}}\left[\mathrm{E}^{2}+\mathrm{E}^{\prime 2}-2 \mathrm{EE}^{\prime}+2\left(\mathrm{E}-\mathrm{E}^{\prime}\right) \mathrm{m}_{\mathrm{e}} \mathrm{c}^{2}\right]$

Izilinganisa lezi 11.7 no 11.8 zitshengisa lokhu: $\mathrm{E}-\mathrm{E}^{\prime}=\frac{\mathrm{EE}^{\prime}}{\mathrm{m}_{\mathrm{e}} \mathrm{c}^{2}}(1-\cos \theta)$.

Njengoba $E=h v=\frac{h c}{\lambda}$, sithola lokhu: 
$\lambda^{\prime}-\lambda=\lambda_{C}(1-\cos \theta)$

$\lambda_{\mathrm{C}}=\frac{\mathrm{h}}{\mathrm{m}_{\mathrm{e}} \mathrm{c}}$ wubude begagasi obuthiwa ngobuka Compton.

Isibonelo

Cabanga inxuku ezimbili zamafothoni anobude bamagagasi $\lambda=0.01 \mathrm{~nm}, \lambda=$ $0.002 \mathrm{~nm}$. Uma inkanyiso ehlakazwa ngama elektoni ayabuzela endawonye iphanjulwa ngenkomba $60^{\circ}$, mkhulu okunganani umehluko wobude bamagagasi amafothoni, eliwelayo neliyinhlakazane kuzo zombili izenzeko?

\section{English}

If I let electromagnetic radiation to be incident on, for example, a block of graphite, I observe another electromagnetic radiation being emitted out of the side of the block - the so called scattered radiation. It is found that the wavelength of the scattered radiation is longer than that of the incident radiation. The difference in the wavelengths of incident and scattered radiations $\Delta \lambda$ increases with the increase in the angle $\theta$, that the scattered radiation makes with the direction of the incident radiation. An explanation of this phenomenon on the basis of the classical wave theory is not possible. However, Compton showed that the scattering could easily be explained if the phenomenon is described as a collision process that is taking place between a photon and a free but stationary electron. 


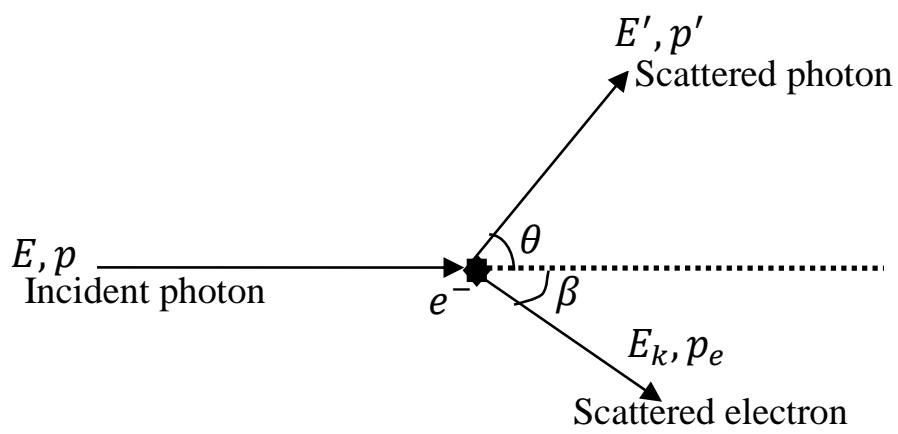

Figure 11: The scattering of a photon that is incident along the $x-a x i s$ by a free and stationary electron. According to the to the energy and momentum conservation laws: $E_{k}=$ $E-E^{\prime}$ and $p_{e}=p-p^{\prime}$, with $p=p^{\prime} \cos \theta+p_{e} \cos \beta$ and $p^{\prime} \sin \theta=p_{e} \sin \beta$

If we apply the conservation laws of energy and momentum, with $\mathrm{p}, \mathrm{E}$ the momentum and the energy of the incident photon respectively, while $\mathrm{p}^{\prime}, \mathrm{E}^{\prime}$ are the momentum and energy of the scattered photon respectively, we find that:

$\mathrm{p}=\mathrm{p}^{\prime}+\mathrm{p}_{\mathrm{e}}$ and $\mathrm{p}_{\mathrm{e}}=\mathrm{p}-\mathrm{p}^{\prime}$

$\mathrm{E}+\mathrm{mc}^{2}=\mathrm{E}^{\prime}+\sqrt{\mathrm{m}_{\mathrm{o}}^{2} \mathrm{c}^{4}+\mathrm{pe}_{\mathrm{e}}^{2} \mathrm{c}^{2}}$

where $p_{e}=p-p^{\prime}$ is the recoil momentum of the electron.

If we square $11.5 p_{e}^{2}=p^{2}+p^{\prime 2}-2 p p^{\prime} \cos \theta ;$ and with $p=\frac{E}{c}=\frac{h v}{c}$ en $p^{\prime}=\frac{E^{\prime}}{c}=\frac{h v}{c}$

we obtain: $p_{\mathrm{e}}^{2}=\frac{1}{\mathrm{c}^{2}}\left(\mathrm{E}^{2}+\mathrm{E}^{\prime 2}-2 \mathrm{EE}^{\prime} \cos \theta\right)$

From 11.6 follows: $\mathrm{p}_{\mathrm{e}}^{2}=\frac{1}{\mathrm{c}^{2}}\left[\mathrm{E}^{2}+\mathrm{E}^{\prime 2}-2 \mathrm{EE}^{\prime}+2\left(\mathrm{E}-\mathrm{E}^{\prime}\right) \mathrm{m}_{\mathrm{e}} \mathrm{c}^{2}\right]$

Equating 11.7 en 11.8 shows that: $\mathrm{E}-\mathrm{E}^{\prime}=\frac{\mathrm{EE}^{\prime}}{\mathrm{m}_{\mathrm{e}} \mathrm{c}^{2}}(1-\cos \theta)$

Since $E=h v=\frac{h c}{\lambda}, 11.9$ can be expressed thus: $\lambda^{\prime}-\lambda=\lambda_{C}(1-\cos \theta)$

where $\lambda_{\mathrm{C}}=\frac{\mathrm{h}}{\mathrm{m}_{\mathrm{e}} \mathrm{c}}$ is called the Compton wavelength. 
Example: Two beams of photons having wavelengths $\lambda=0.1 \mathrm{~nm}$ and $\lambda=0.002 \mathrm{~nm}$ are each scattered by free electrons. If the scattering angle is $\theta=60^{\circ}$, what is the magnitude of the difference in wavelengths of the photons before and after each has been scattered? 


\section{Appendix B}

Vocabulary in Dutch, isiNguni and English for Appendix A

\begin{tabular}{|c|c|c|c|}
\hline Nederlands (Dutch) & IsiNguni & Literal Translation & English \\
\hline $\begin{array}{l}\text { electromagnetisch } \\
\text { straling }\end{array}$ & ucwazima lowongagetsi & $\begin{array}{l}\text { the radiation of } \\
\text { electromagnetism }\end{array}$ & $\begin{array}{l}\text { electromagnetic } \\
\text { radiation }\end{array}$ \\
\hline verstroide straling & $\begin{array}{l}\text { ucwazima } \\
\text { oluyinhlakazane }\end{array}$ & $\begin{array}{l}\text { the radiation that is } \\
\text { spread about }\end{array}$ & scattered radiation \\
\hline golflengte & ubude begagasi & the length of a wave & wavelength \\
\hline $\begin{array}{l}\text { golflengteveranderi } \\
\operatorname{ng} \Delta \lambda\end{array}$ & $\begin{array}{l}\text { umahluko wobude } \\
\text { bamagagasi } \Delta \lambda\end{array}$ & $\begin{array}{l}\text { the difference in the } \\
\text { lengths of the waves }\end{array}$ & $\begin{array}{l}\text { the wavelength } \\
\text { difference } \Delta \lambda\end{array}$ \\
\hline verstrooiingshoek $\theta$ & $\begin{array}{l}\text { izinga lenkomba } \\
\theta \text { yenhlakazane }\end{array}$ & $\begin{array}{l}\text { the degree of the } \\
\text { scattering } \theta\end{array}$ & $\begin{array}{l}\text { the scattering angle } \\
\theta\end{array}$ \\
\hline verschijnsel & isibonakaliso & that which is observed & phenomenon \\
\hline $\begin{array}{l}\text { klassieke } \\
\text { golftheorie }\end{array}$ & $\begin{array}{l}\text { infunisela yendulo } \\
\text { ngamagagasi }\end{array}$ & $\begin{array}{l}\text { that which was thought } \\
\text { to be about waves }\end{array}$ & $\begin{array}{l}\text { classical wave } \\
\text { theory }\end{array}$ \\
\hline botsingsproces & $\begin{array}{l}\text { isenzeko } \\
\text { songquzulwana }\end{array}$ & the process of colliding & collision process \\
\hline sfoton & $\begin{array}{l}\text { ifothoni / } \\
\text { uhlanvulwelanga }\end{array}$ & $\begin{array}{l}\text { photon/a particle of the } \\
\text { sun }\end{array}$ & photon \\
\hline $\begin{array}{l}\text { stilstande vrij } \\
\text { elektron }\end{array}$ & $\begin{array}{l}\text { elekthoni eliyabuzela } \\
\text { lindawonye }\end{array}$ & $\begin{array}{l}\text { electron that wonders } \\
\text { around the same } \\
\text { location }\end{array}$ & $\begin{array}{l}\text { free and stationary } \\
\text { electron }\end{array}$ \\
\hline toepasing & ukusebenzisa & if we use & if we apply \\
\hline vetten van behoud & imithetho yokongeka & laws of conservation & $\begin{array}{l}\text { laws of } \\
\text { conservation }\end{array}$ \\
\hline impuls en energie & $\begin{array}{l}\text { isivungudla ne } \\
\text { sidlakadla }\end{array}$ & $\begin{array}{l}\text { that which blows } \\
\text { forcefully and energy }\end{array}$ & $\begin{array}{l}\text { momentum and } \\
\text { energy }\end{array}$ \\
\hline invallende foton & ifothoni eliwelayo & $\begin{array}{l}\text { the photon that falls } \\
\text { onto }\end{array}$ & incident photon \\
\hline $\begin{array}{l}\text { terugslag impuls } \\
\text { van een elektron }\end{array}$ & $\begin{array}{l}\text { isivungudla elekthoni } \\
\text { elikwincika ngaso }\end{array}$ & $\begin{array}{l}\text { the momentum with } \\
\text { which the electron } \\
\text { recoils }\end{array}$ & $\begin{array}{l}\text { the recoil } \\
\text { momentum }\end{array}$ \\
\hline kwadrateer $\mathrm{p}_{\mathrm{e}}$ & $\begin{array}{l}\text { uma } p_{e} \text { angaphiwa } \\
\text { amandla kabili }\end{array}$ & if $\mathrm{p}_{\mathrm{e}}$ is powered twice & if $p_{e}$ is squared \\
\hline vergelijking & isilinganisa & that which equates & equation \\
\hline
\end{tabular}

